http://jmscr.igmpublication.org/home/

ISSN (e)-2347-176x ISSN (p) 2455-0450

crossref DOI: https://dx.doi.org/10.18535/jmscr/v8i5.90

\title{
A Study of Functional Outcome of Advanced Osteoarthritis Knee Treated with Total Knee Arthroplasty
}

\author{
Authors \\ Dr Jithin Jose ${ }^{1}$, Dr Balagopalan $\mathrm{K}^{2 *}$, Dr Sabarisree $\mathbf{M}^{3}$ \\ ${ }^{1}$ Senior Resident, Govt Medical College, Thrissur \\ ${ }^{2}$ Additional Professor In Orthopaedics, Govt Medical College, Thiruvananthapuram \\ ${ }^{3}$ Additional Professor In Orthopaedics, Govt Medical College, Thiruvananthapuram \\ *Corresponding Author \\ Dr Balagopalan K \\ Additional Professor In Orthopaedics, Govt Medical College, Thiruvananthapuram, India
}

\begin{abstract}
Introduction: Osteoarthritis is thought to be the most prevalent chronic joint disease. The incidence of arthritis is increasing because of ageing population and rise of obesity. Total knee arthroplasty is now the reliable technique for severe arthritis. Many designs are available with different type of prosthesis it is important to study the outcome of prosthetic replacement. Different types of scoring system are used to assess the functional outcome. Of this the most important is the knee society scoring system. In 1989, the Knee Society published its revised knee rating system

Objectives of the Study: 1, To study the Functional Outcome of Advanced Osteoarthritis Knee Treated with Total Knee Arthroplasty.2, To compare the knee society knee score preoperatively and postoperatively

Methodology

Study Design: Prospective study

Study Setting: Department of Orthopedics, Government Medical College Thrissur.

Inclusion Criteria: 1, Patient with advanced arthritis knee as per radiological grading 2, Consenting patients 3, Age: Adult patients > 18 years4, Sex: Both male and female5, Physical fitness for surgery

Exclusion Criteria: 1, Patients managed conservatively for other medical reasons 2, Any comordity that prevents patient from early mobilisation 3, Pre-operative fractures 4, Post-operative infection

Sample Size: All patients attending orthopedics department of MCH Thrissur fulfilling inclusion criteria during the study period

Procedure: Key features of the proposed surgical technique includes General Anesthesia/Spinal Anesthesia, supine with knee in 90 degree flexion, Tourniquet control, midline skin incision, medial parapatellar approach, distal femoral cut at a valgus angle (usually 5 to 7 degrees), rotational alignment, Cut the tibia perpendicular to its mechanical axis with 0 to 5 degrees of posterior slope, GAP TECHNIQUE by spacer blocks, Femoral Sizer, Anterior, Posterior and Chamfer Resection, Tibial Stem Preparation, bone grafting of defects, Trial Reduction component placement, Extensor Mechanism Repair, wound closure. The patient was assessed 6 weeks post operatively for any signs of post operative infection. Once post operative infection was ruled out clinically the patient was assessed clinically and functionally using the Knee Society Score at an interval of 3 months and 6 months. Other complications were also looked for and treated appropriately.

Discussion: Elderly patients who were having difficulty in mobilizing because of degenerative arthritis found good relief after Total Knee Arthroplasty. All the parameters measured and results obtained were comparable with literature and the results were showing a excellent outcome

Conclusion: All the patients were treated with posterior cruciate substituting type of total knee arthroplasty. At 6 months follow up knee clinical score improved from an average of 27 to 87.90showing an excellent outcome and knee functional score improved from an average of 40 to 81.05 showing an excellent outcome and patients were able to have pain free mobile joint.
\end{abstract}




\section{Introduction}

According to Symmons et al osteoarthritis is a 'condition characterised by the focal areas of loss of cartilage within synovial joint, associated with hypertrophy of the bone (osteophyte and subchondral bone sclerosis) and thickening of the capsule'. There is usually joint space narrowing and osteophyte formation as seen in $\mathrm{x}$-ray ${ }^{1}$

Most prevalent chronic joint disease is considered to be osteoarthritis. Incidence of osteoarthritis is on the rise because of increase in longevity in the population and obesity. Main clinical features that lead to treatment which include both surgical and non-surgical arepain and loss of function ${ }^{2}$

The common causes of arthritis of the knee include Primary Osteoarthritis, Rheumatoid Arthritis, Juvenile Rheumatoid Arthritis, Post traumatic Arthritis or secondary Osteoarthritis and other inflammatory arthritis.

From 19th century the concept for improvement of knee joint function by modifying the articular surfaces has been studied. The surgical techniques have varied from soft tissue interposition arthroplasty to resection arthroplasty to surface replacement arthroplasty.

Total Knee Arthroplasty is now a reliable treatment for advanced arthritis. Many systems are available with specific features regarding the degree of conformity of the articulating surface, the geometry of the components, and the anchoring technique. With the advent of these varied types of prosthesis it became necessary to conduct studies for assessing the outcome of prosthesis of different types. It can be measured by the Knee Society Scoring system. The Knee Society Score System is subdivided into two for measurement - clinical and functional score ${ }^{3}$

Hence it was planned to conduct the study on 40 patients with advanced osteoarthritis knee treated with Total Knee Arthroplasty to assess the clinical and functional outcome using Knee Society Scoring system

\section{Aim}

To study the clinical and functional outcome of Total Knee Arthroplasty in a series of patients with advanced osteoarthritis knee using knee society score

\section{Objective}

1. To compare knee society clinical score preoperatively and postoperatively in patients with advanced osteoarthritis knee with Total Knee Arthroplasty

2. To compare knee society functional score preoperatively and postoperatively in patients with advanced osteoarthritis knee with Total Knee Arthroplasty

\section{Methodology \\ Materials and Methods}

Study Design : Prospective study

Study Setting: Department of Orthopedics, Government Medical College Thrissur.

Study Period: 1-3-2015 to 30-9-2016

Study Duration: 18 months [12 months' data collection+6months follow up]

Sample Size: All patients attending orthopedics department of $\mathrm{MCH}$ Thrissur during the study period and who fulfill the inclusion criteria

\section{Inclusion Criteria}

1. Patient with advanced arthritis knee as per radiological grading ${ }^{103}$

2. Consenting patients

3. Age: Adult patients $>18$ years

4. Sex: Both male and female

5. Physical fitness for surgery

\section{Exclusion Criteria}

1. Patients managed conservatively for other medical reasons

2. Any co-mordity that prevents patient from early mobilisation

3. Pre- operative fractures

4. Post-operative infection

\section{Methodology}

The following data were obtained for all study patients as per the Proforma attached below: Age, Sex, Occupation, Socioeconomic Status, Side, Co Morbidities.

After proper history taking, clinical examination, 
radiological work up, pre operative work up and informed written consent, patients were taken up for surgery after assessing pre operative knee society score. Surgery was done by the guide with the assistance of the principal investigator. Patients were taken up for surgery as early as possible after general blood and radiological work up

\section{Procedure}

After scrubbing, cleaning and draping patient was positioned in 90 degree of knee flexion, tourniquet control and an anterior midline incision was made. Incision was from $3 \mathrm{~cm}$ to $5 \mathrm{~cm}$ above the superior pole of patella to below the level of the tibial tubercle.

Medial parapatellar retinacular approach was taken to open the joint so as to gain easy access to the diseased medial compartment and prevent fibrosis over the lateral side of patella which will predispose to patella dislocation post operatively.

The patella was retracted laterally. The retro patellar fat pad was excised. With the knee extended, subperiosteal sleeve of soft tissue was elevated from the proximal medial tibia, medial collateral ligament. Elevation was continued with a periosteal elevator and the posterior fibers were freed. So as to improve the exposure during the release, subperiosteal sleeve was retracted using a retractor preferably Homans retractor. The insertion of the semimembranosus muscle from the posteromedial tibia is released. Continue the release distally to the anteromedial surface of the tibia and strip the periosteum medially. For severe deformities, continue subperiosteal stripping posteriorly and distally. If flexion contracture was present, release or transversely divide the posterior capsule. If it was valgus deformity do a lateral soft tissue release according to the extent of the deformity.

The Whiteside line and the Trans-epicondylar line were made over the femoral condyles after exposing the condyles. Whiteside line is the vertical line cutting through the middle of distal femoral sulcus. Trans-epicondylar line is the horizontal line linking the medial and lateral epicondyle. The starter hole was created at the intersection between the vertical Whiteside Line and the horizontal Epicondylar Line. The hole was placed medial and anterior to the anteromedial corner of the intercondylar notch

Distal femur was resected with the standard resection slot. Assemble the Distal Resection Guide and Valgus Alignment Guide onto the intramedullary alignment rod. The 5 to 7 degree valgus cut was made in order to get a distal cut that is perpendicular to the mechanical axis. Resect the distal femur using the standard resection slot which provides a $9 \mathrm{~mm}$ resection from the prominent distal condyle.

The extramedullary tibial guide was assembled. The long axis of the tibial resection guide should be parallel to the tibia. The resection slot should be located a few millimeters below the lowest articular surface (usually medial). Use the stylus to check the amount of tibial cut $2 \mathrm{~mm}$ for medial referencing, $10 \mathrm{~mm}$ for lateral referencing. The final tibial cut was completed with an osteotome to prevent over penetration of saw blade posteriorly which risked popliteal artery cut.

The extension gap was checked and should be able to accept a minimum of $10 \mathrm{~mm}$ base. A symmetrical and rectangular extension gap must be obtained. The extension gap must be the same as flexion gap. Then femoral sizing was done

Place the femoral resection block flush against the distal and anterior femoral surfaces. Stabilize the block. The recommended order of resection is: 1 . Posterior, 2. Posterior chamfer, 3. Anterior, 4. Anterior chamfer.

The tibial insert size must match the femoral implant size. There are two tibial base sizes that can be used with any one size femoral component. An alignment rod can be inserted through the handle to check alignment to the ankle anterior superior iliac spine; patella and $2^{\text {nd }}$ toe should be on same level

Attach the keel punch guide to the keel punch handle and secure it to the trial base by turning the knurled handle. Using the threaded punch handle and appropriate keel punch, slide the punch through the guide until the punch is fully seated.

The trial base and stem were left in place for a 


\section{JMSCR Vol||08||Issue||05||Page 512-530||May}

trial reduction. After satisfactory reduction, the patella was denervated circumferentially using the cautry. Place the appropriate size femoral trial on the distal femur using the femoral impactor and trial reduction was checked

Bone cement was spread over the cut surfaces of femur and tibia for preparing for the femoral and tibial component implantation. Once the cement surrounding the tibial base has cured, the appropriate tibial insert may be locked into place After attaining hemostasis and a drain was put Wound was closed in layers using 1-0 vicryl starting with closure of capsule, subcutaneous sutures and skin was closed in staplers. Post operative dressings were given and knee was immobilized in a long knee brace. Operation details were recorded and patient was shifted to post operative ward

\section{Operative Photographs}

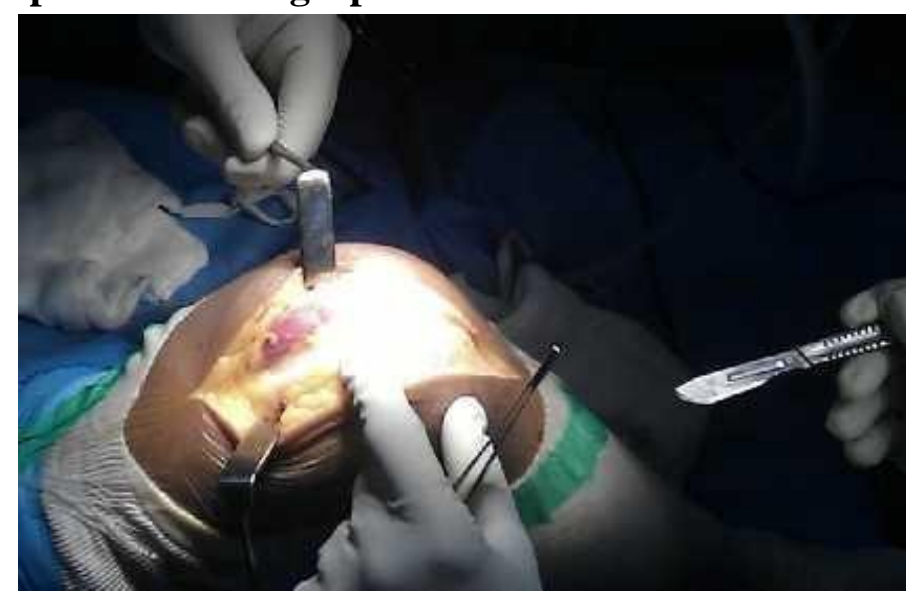

Figure 24: Medial parapatellar approach

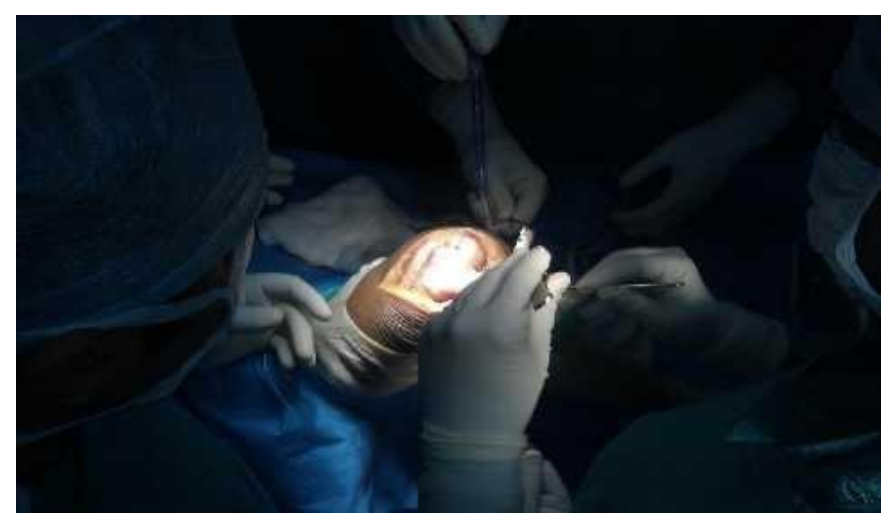

Figure 25: Joint opened

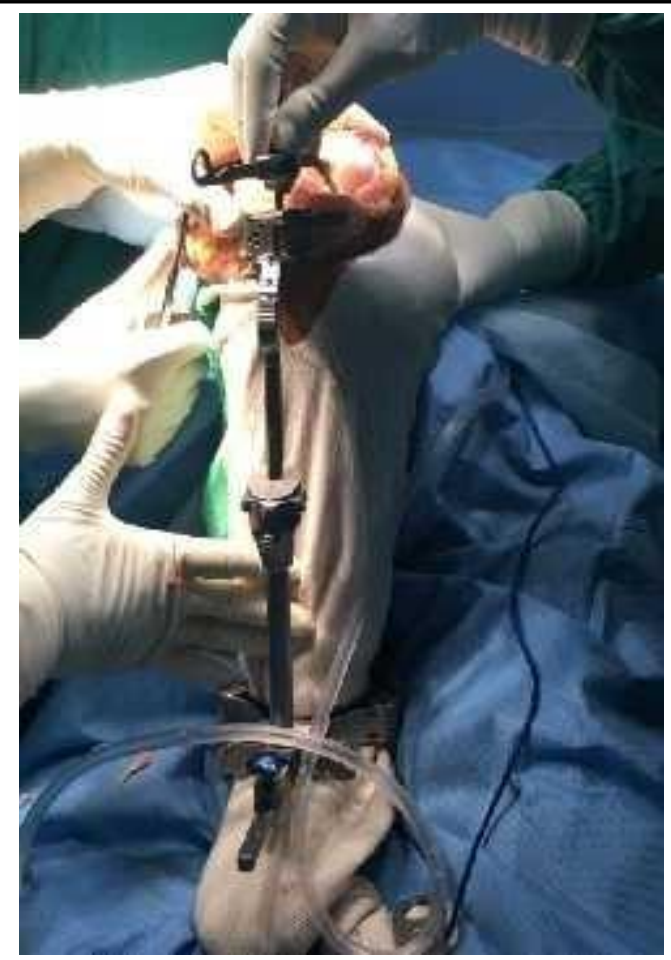

Figure 26: Extramedullary alignment of tibia

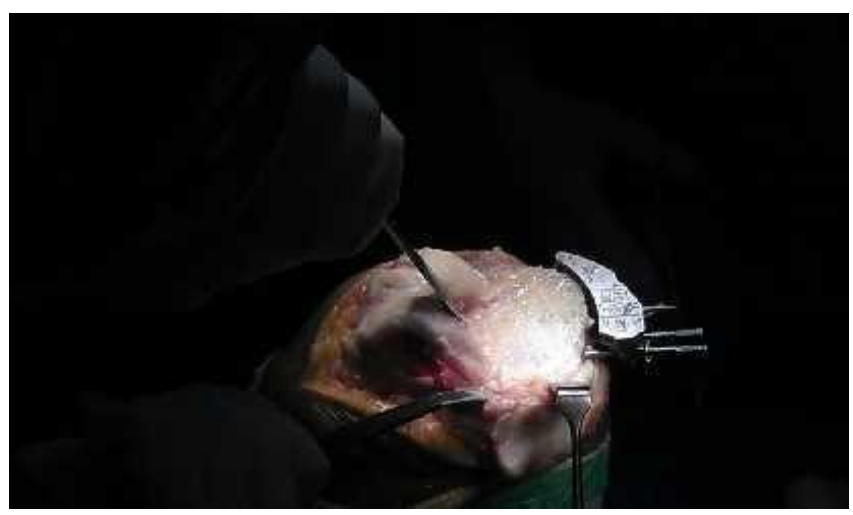

Figure 27: Tibial cut

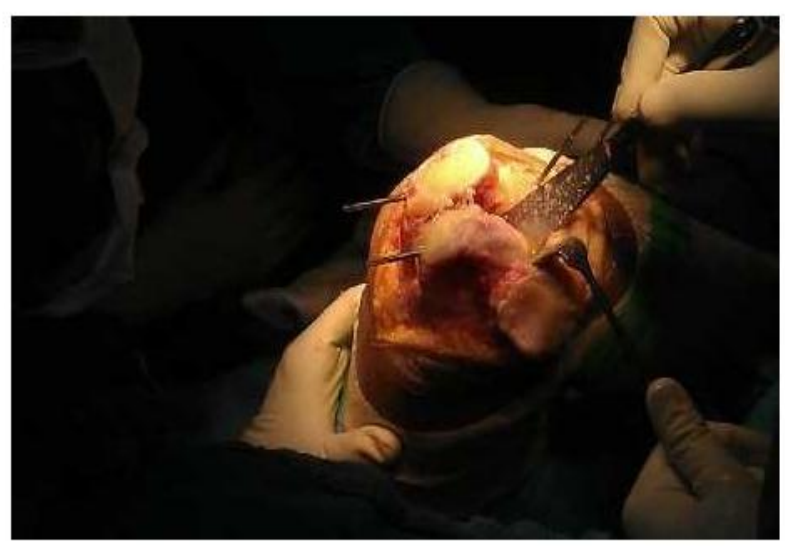

Figure 28: Femoral cut 


\section{JMSCR Vol||08||Issue||05||Page 512-530||May}

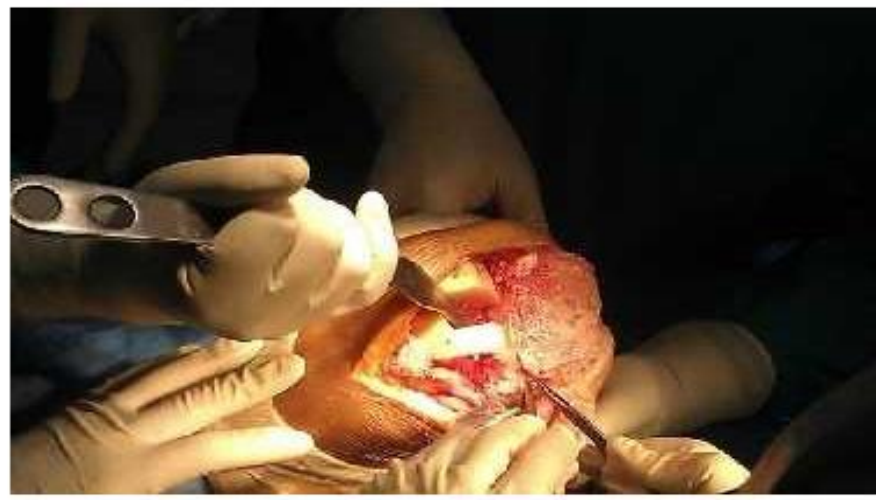

Figure 29: After completing cuts

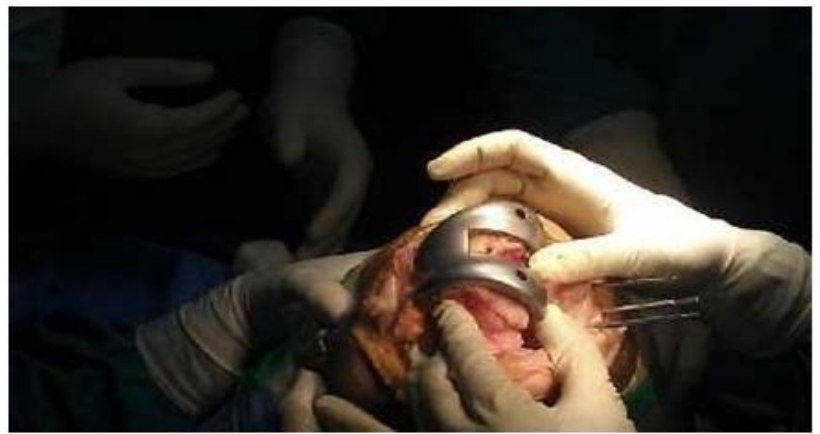

Figure 30: Trial insertion after checking extension and flexion gap

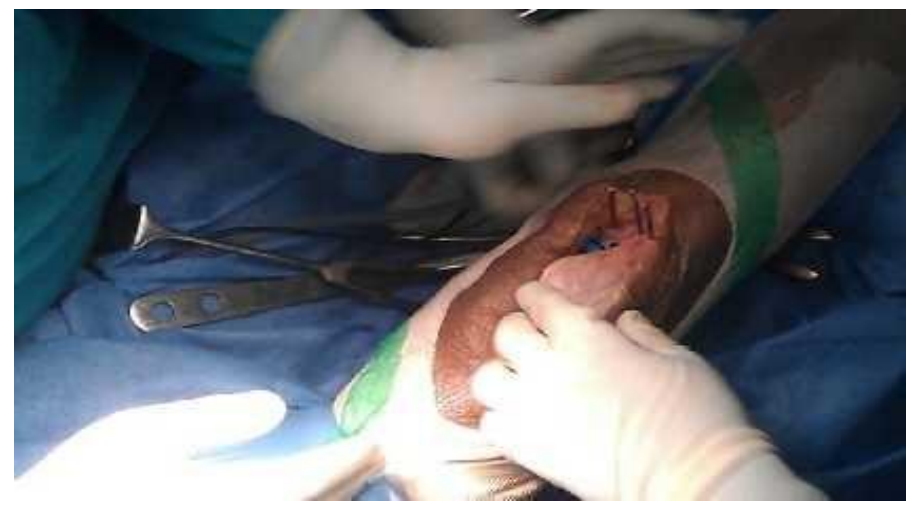

Figure 31: Checking alignment after trial insertion

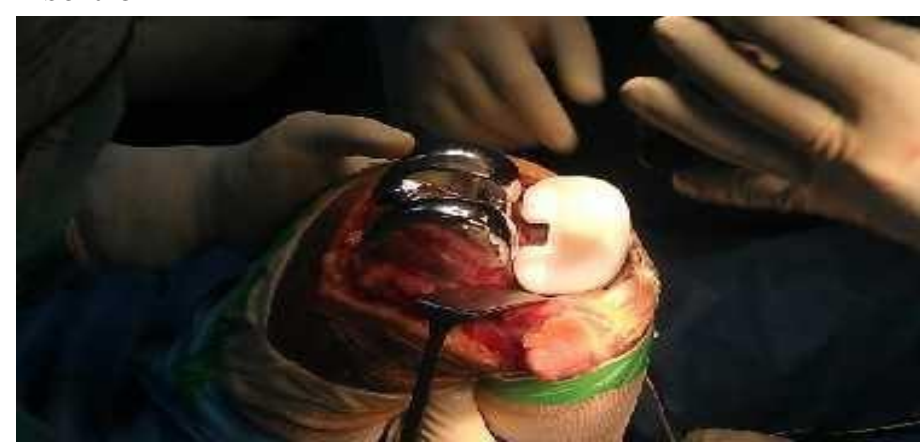

Figure 32: Both tibial and femoral component insertion

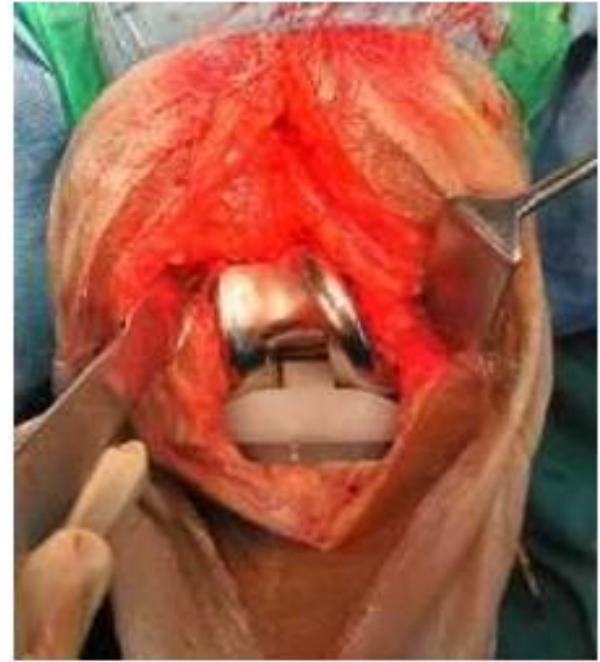

Figure 33: After reduction

\section{Post-operative Protocol}

Post Operative Protocol which included compression bandage and long knee brace from day 1, Early Mobilization on Day 3 with dressing change and drain removal, dressing change every 3 days, $4^{\text {th }}$ post op day knee flexion and dynamic quadriceps exercise, intravenous antibiotics from day 1 , suture removal on post op day 12 with continuation of physiotherapy were done

\section{Follow-up}

The patient was assessed 6 weeks post operatively for any signs of post operative infection. Once post operative infection was ruled out clinically the patient was assessed clinically, functionally using the Knee Society Score at an interval of 3 months, 6 months. Knee Society Score included both clinical and functional scores. In clinical score pain, range of motion, alignment, contractures and deformities were assessed and score were given. In functional score walking distance, climbing stairs and need of support were assessed. Other complications were looked for and treated appropriately. Scores were given excellent [80-100], good [70-79], fair [60-69], poor [>60]

\section{Observations and Results}

The following observations were made from the data collected from 40 patients with advanced osteoarthritis knee treated with total knee 
arthroplasty in Government Medical College, Thrissur during the period 1-3-2015 to 30-9-2016

\section{Age distribution}

Table 2: Age distribution

\begin{tabular}{|c|c|c|c|c|c|}
\hline Age & $46-55$ & $56-65$ & $66-75$ & $76-85$ & TOTAL \\
\hline $\begin{array}{c}\text { No. of } \\
\text { Cases }\end{array}$ & 8 & 17 & 12 & 3 & 40 \\
\hline Percentage & 20 & 42.5 & 30 & 7.5 & 100 \\
\hline
\end{tabular}

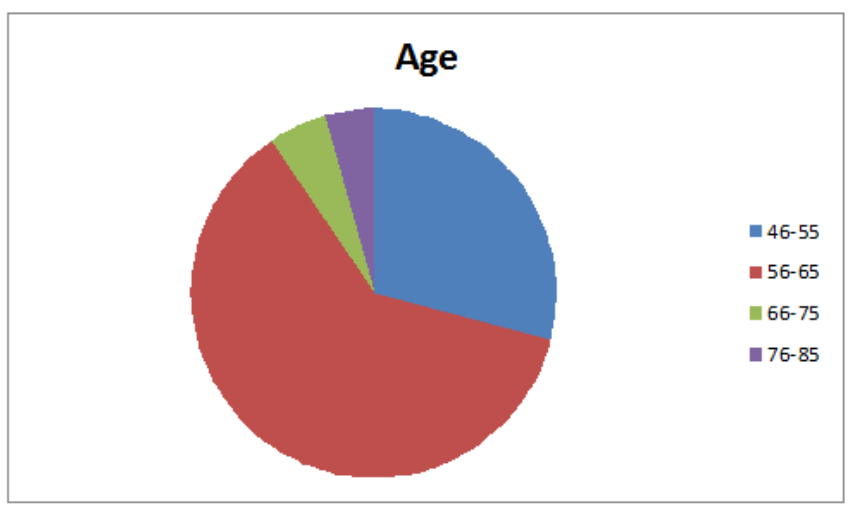

Graph 1: Age Distribution

In this study most of the age group were from 5665 which was $42.5 \%$ followed by $66-75$ which was $30 \%$

\section{Sex Distribution}

Table 3: Sex distribution

\begin{tabular}{|c|c|c|}
\hline SEX & $\begin{array}{c}\text { No. OF } \\
\text { PATIENTS }\end{array}$ & PERCENTAGE \\
\hline MALE & 8 & 20 \\
\hline FEMALE & 32 & 80 \\
\hline TOTAL & 40 & 100 \\
\hline
\end{tabular}

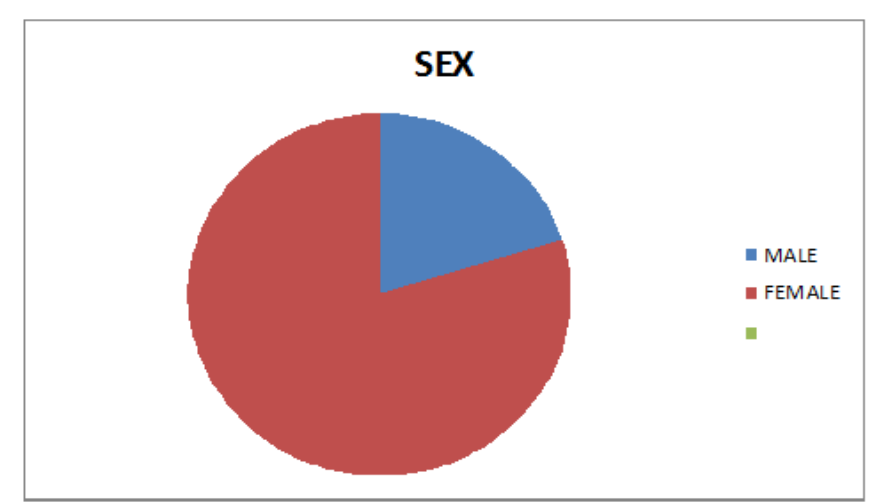

Graph 2: Sex Distribution
Out of the 40 patients, $32(80 \%)$ were females. This could be due to higher incidence of osteoarthritis in females

\section{Side Distribution}

Table 4: Side distribution

\begin{tabular}{|l|c|c|c|}
\hline & Right & Left & Total \\
\hline No of cases & 18 & 22 & 40 \\
\hline Percentage & 45 & 55 & 100 \\
\hline
\end{tabular}

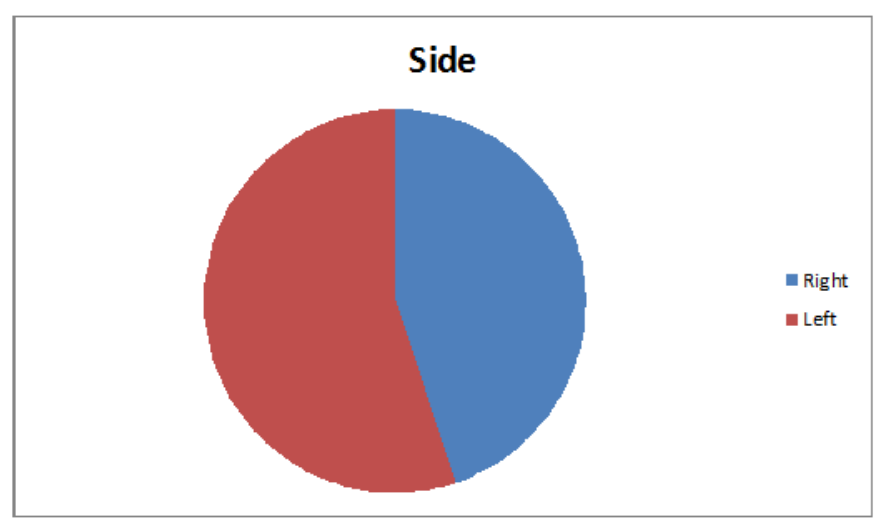

Graph 3: Side distribution

Out of 40 cases operated 22 cases were operated on the left side which accounts for $55 \%$ of the cases

\section{Functional Outcome}

\section{Knee Clinical Score}

Table 5: Functional outcome of Knee clinical score

\begin{tabular}{|c|c|c|}
\hline KCS & Number & Percentage \\
\hline Excellent & 34 & 89.4 \\
\hline Good & 3 & 7.8 \\
\hline Fair & 0 & 0 \\
\hline Poor & 1 & 2.6 \\
\hline Total & 38 & 100 \\
\hline
\end{tabular}

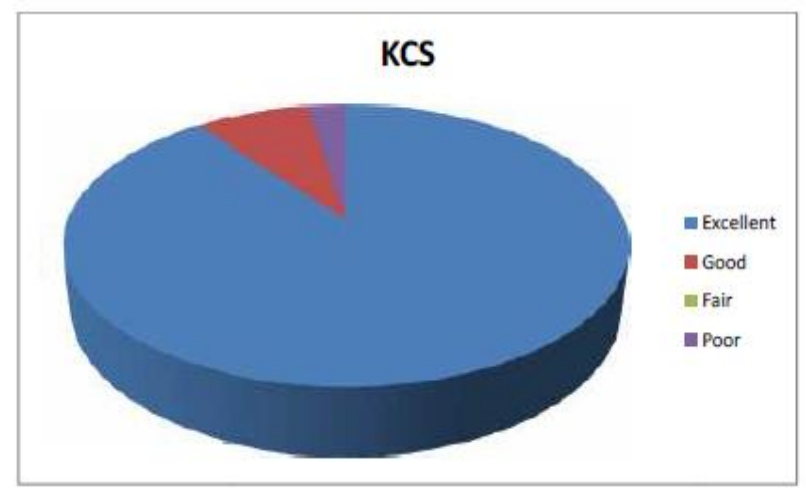

Graph 4: Functional outcome of Knee clinical score 


\section{JMSCR Vol||08||Issue ||05||Page 512-530||May}

40 patients who were done surgery 34 had excellent knee clinical score after 6 months 3 had good results and 1 had poor results 2 patients were excluded due to postoperative infections.

\section{Comparison of knee clinical score}

Table 6: Knee clinical score comparison

\begin{tabular}{|c|c|c|c|}
\hline & $\mathrm{N}$ & MEAN & $\begin{array}{c}\text { STANDARD } \\
\text { DEVIATION }\end{array}$ \\
\hline Pre-op & 40 & 27 & 6.06 \\
\hline $\begin{array}{c}\text { Post-op[3 } \\
\text { months] }\end{array}$ & 38 & 85.47 & 8.16 \\
\hline $\begin{array}{c}\text { Post-op[6 } \\
\text { months] }\end{array}$ & 38 & 87.90 & 7.03 \\
\hline
\end{tabular}

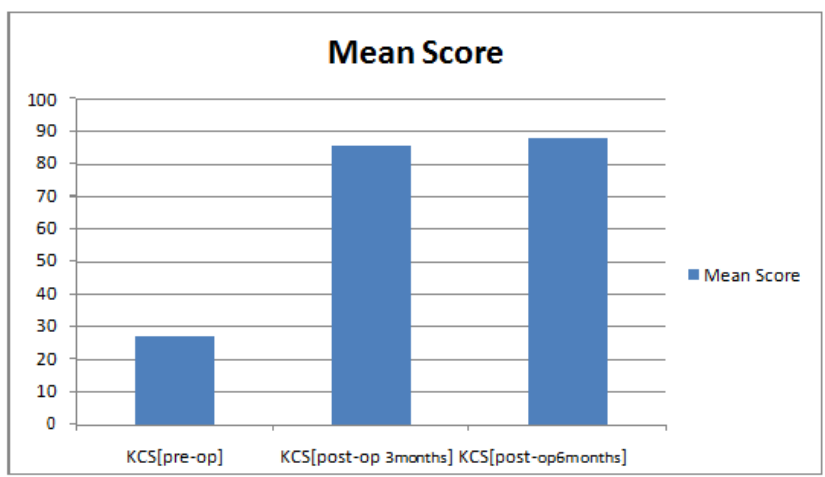

Graph 5: Knee clinical score comparison

38 patients who underwent surgery had a mean pre-op score of 27 with a standard deviation of 6.06. After 3 months the mean post-op score was found to have increased to 85.47 with a standard deviation of 8.16 which further increased to 87.90 with a standard deviation of 7.03 indicating an excellent outcome

\section{Knee Functional Score}

Table 7: Functional outcome of Knee functional score

\begin{tabular}{|l|l|l|}
\hline KFS & Number & Percentage \\
\hline Excellent & 28 & 73.6 \\
\hline Good & 8 & 21.05 \\
\hline Fair & 1 & 2.6 \\
\hline Poor & 1 & 2.6 \\
\hline Total & 38 & 100 \\
\hline
\end{tabular}

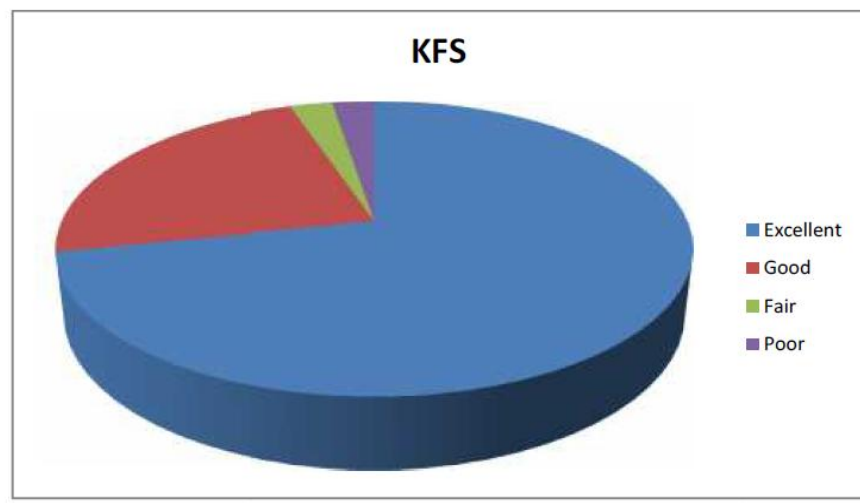

Graph 6: Functional outcome of Knee functional score

Out of the 40 patients operated 28 had excellent outcome with which was $73.6 \%$ and 8 had good results and one each had fair and poor results. 2 were excluded from study due to post operative infection

Table 8: Knee functional score comparison comparison of knee functional score

\begin{tabular}{|c|c|c|c|}
\hline & $\mathbf{N}$ & MEAN & $\begin{array}{l}\text { STANDARD } \\
\text { DEVIATION }\end{array}$ \\
\hline Pre-op & 40 & 40.37 & 7.71 \\
\hline $\begin{array}{l}\text { Post-op[3 } \\
\text { months] }\end{array}$ & 38 & 78.28 & 7.63 \\
\hline $\begin{array}{l}\text { Post-op[6 } \\
\text { months] }\end{array}$ & 38 & 81.05 & 7.18 \\
\hline
\end{tabular}

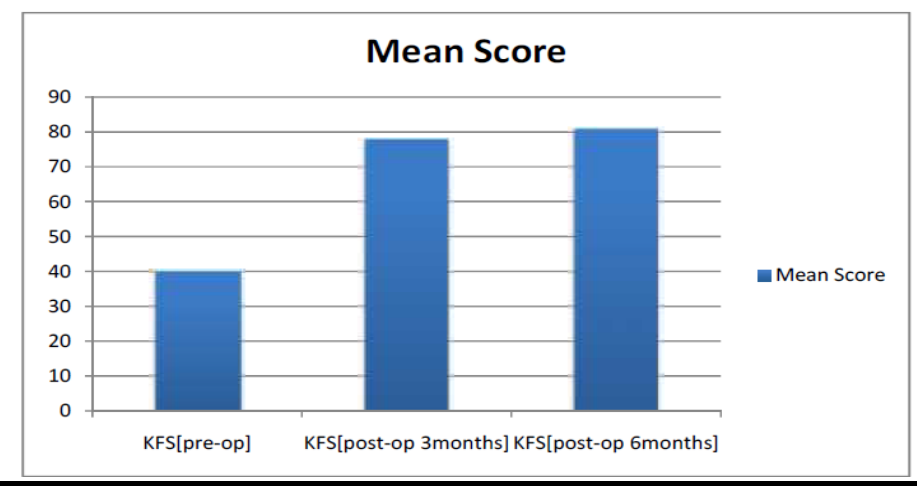

Graph 7: Knee functional score comparison

40 patients who underwent surgery had a mean pre-op score of 40.37 with a standard deviation of 7.71. After 3 months post operative score was found to have increased to 78.28 with a standard deviation of 7.63 which further increased to 81.05 with a standard deviation of 7.18indicating an excellent outcome 


\section{JMSCR Vol||08||Issue ||05||Page 512-530||May}

Difference in outcome of knee society score in valgus and varus knee

Knee Clinical Score

Table 9: Knee clinical score in varus and valgus

knee

\begin{tabular}{|c|c|c|c|c|c|}
\hline ALIGNMENT & Excellent & Good & Fair & Poor & Total \\
\hline VARUS & $28(90.4 \%)$ & $2(6.4 \%)$ & $0(0 \%)$ & $1(3.2 \%)$ & $31(100 \%)$ \\
\hline VALGUS & $6(85.7 \%)$ & $1(14.2 \%)$ & $0(0 \%)$ & $0(0 \%)$ & $7(100 \%)$ \\
\hline
\end{tabular}

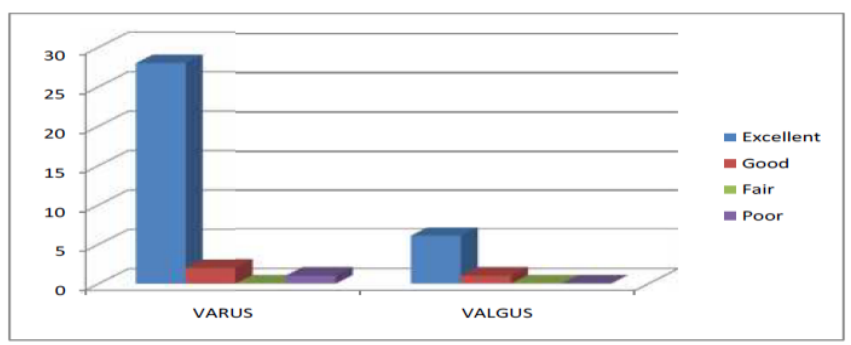

Graph 8: Knee clinical score in varus and valgus knee

Out of 38 patients who underwent surgery 31 had varus knee and 7 had valgus knee. On follow up it was seen that $28(90.4 \%)$ among the 31 had excellent outcome, 2(6.4\%) had a good outcome and $1(3.2 \%)$ had poor outcome. Among the 7 with valgus knee $6(85.7 \%)$ had an excellent outcome, $1(14.2 \%)$ had good outcome and none had poor results

Table 10: Knee functional score in varus and valgus knee

KNEE FUNCTIONAL SCORE
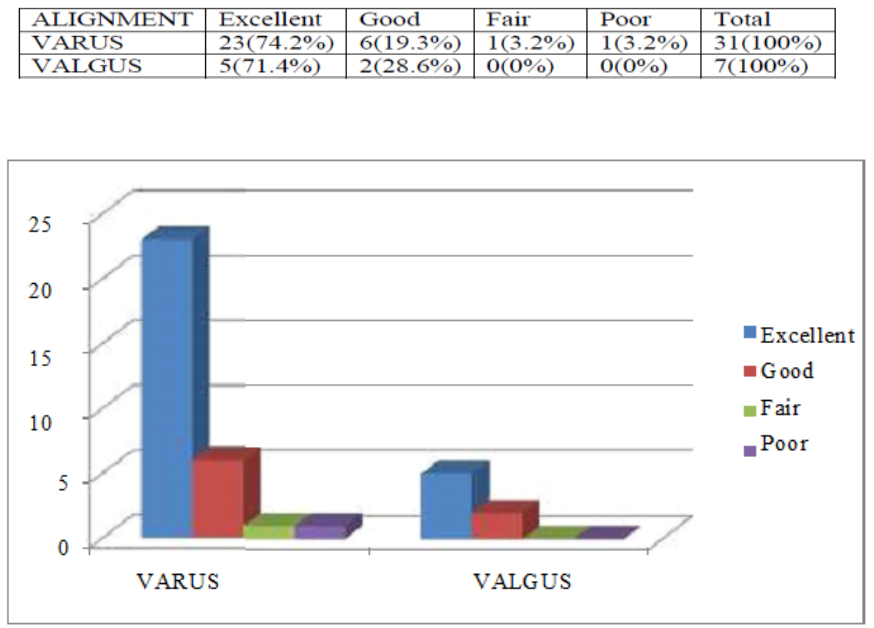

Graph 9: Knee functional scorein varus and valgus knee
Out of 38 patients who underwent surgery 31 had varus knee and 7 had valgus knee. On follow up it was seen that 23(74.2\%) among the 31 had excellent outcome,6(19.3\%) had a good outcome, $1(3.2 \%)$ had a fair outcome and 1(3.2\%) had poor outcome. Among the 7 with valgus knee 5(71.4\%) had an excellent outcome,2(28.6\%)had good outcome and none had poor results

\section{Clinical and Radiological Photographs}

Case no: 1
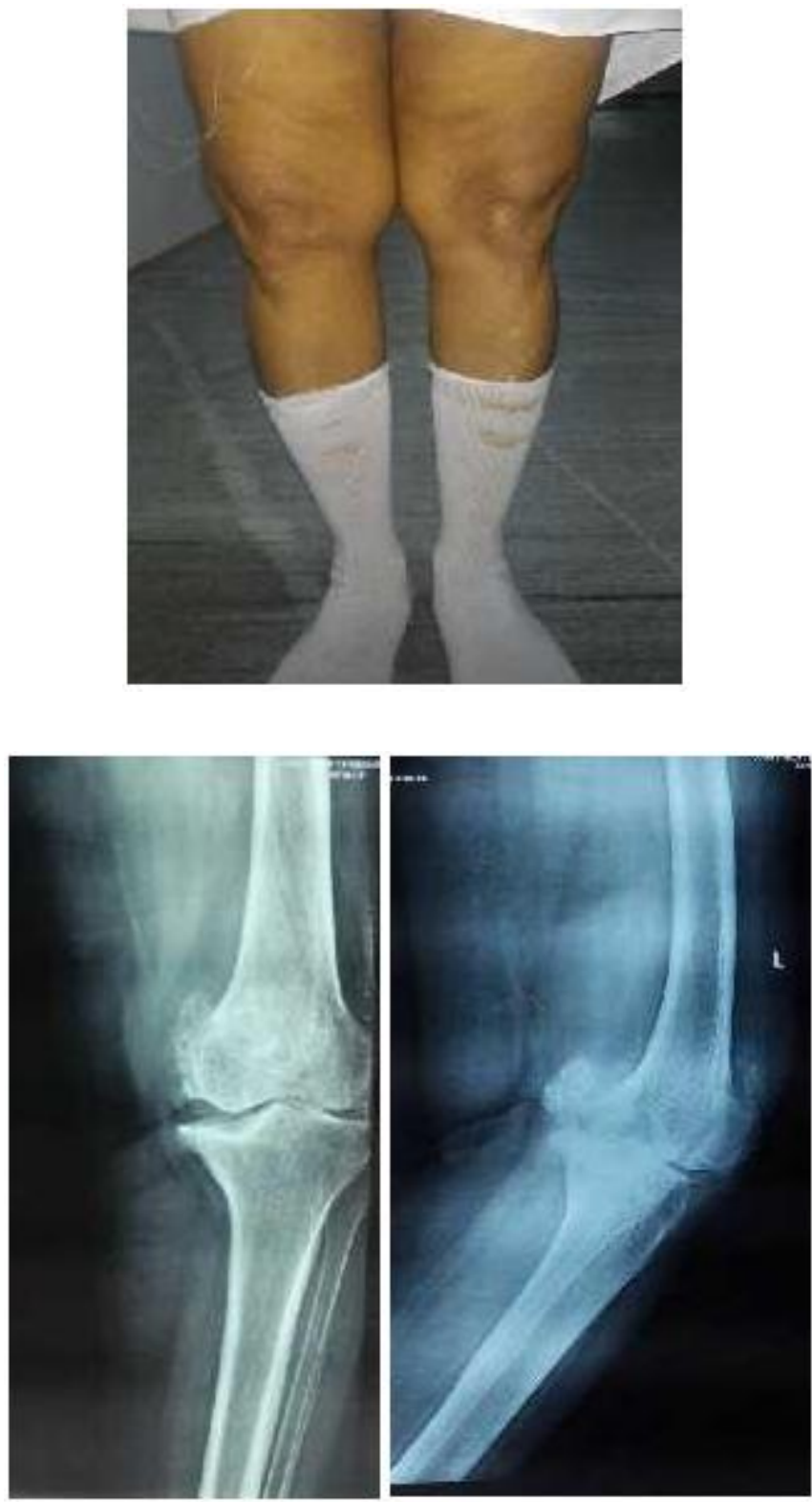

Figure 34.2: Pre operative radiograph 


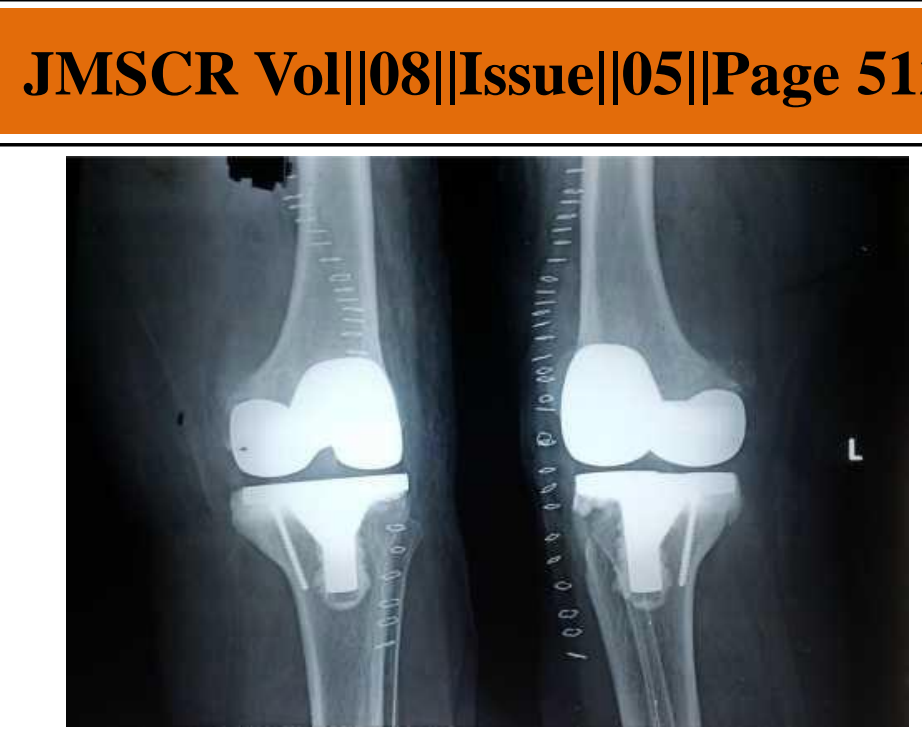

Figure 34.3: Post operative radiograph

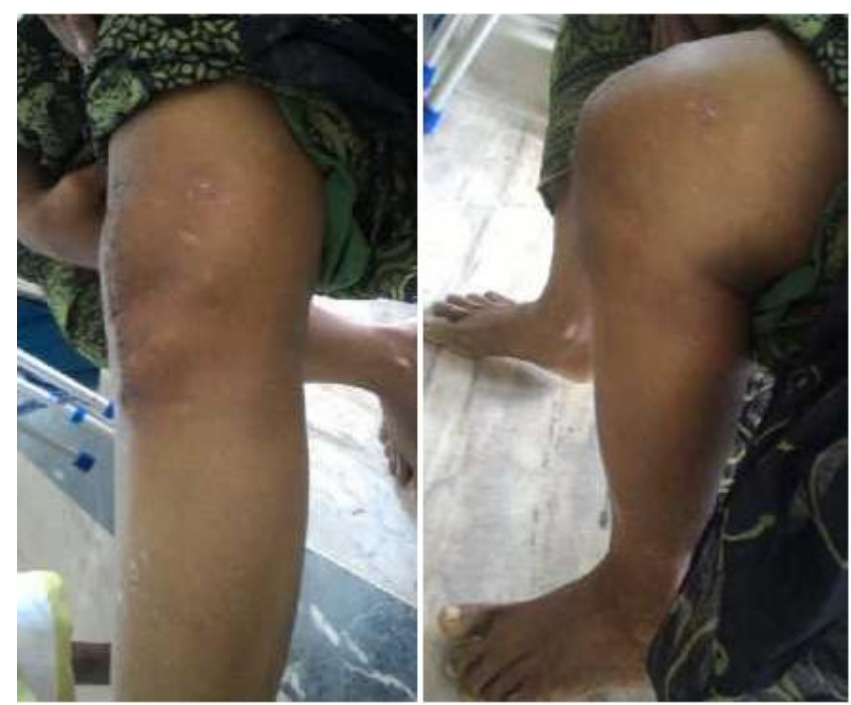

Figure 34.4: Range of motion after 6 month

Case no: 2

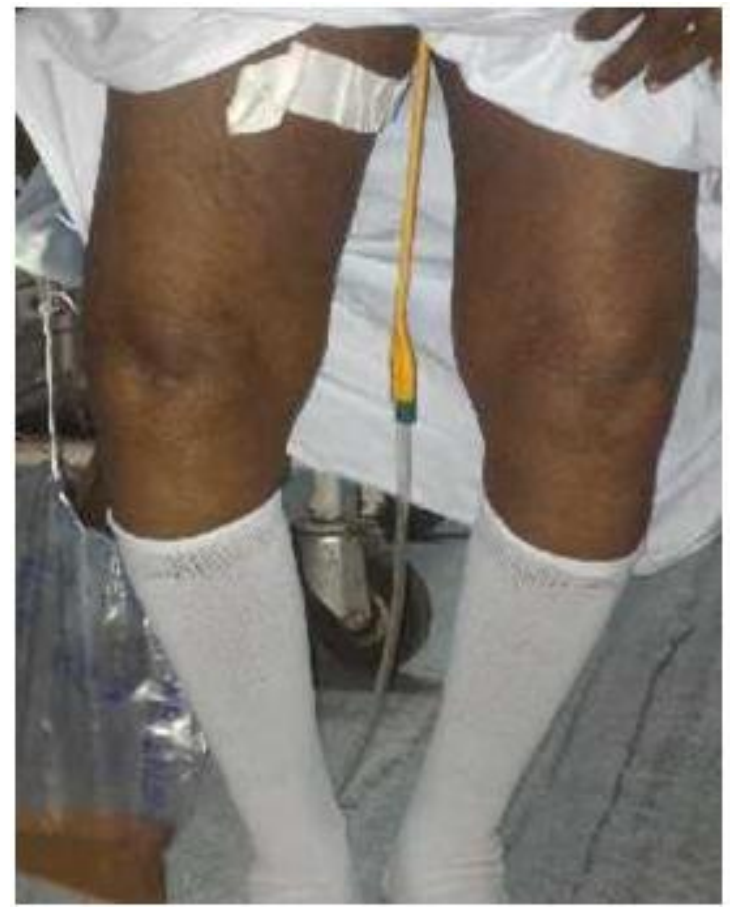

Figure 35.1: Pre operative picture

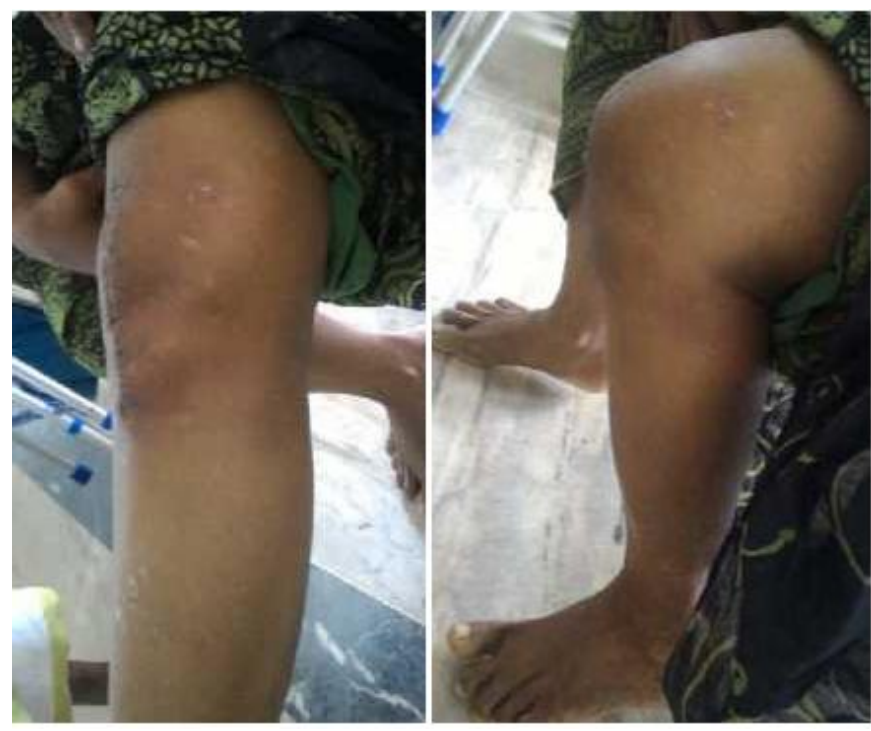

Figure 35.2: Pre operative radiograph

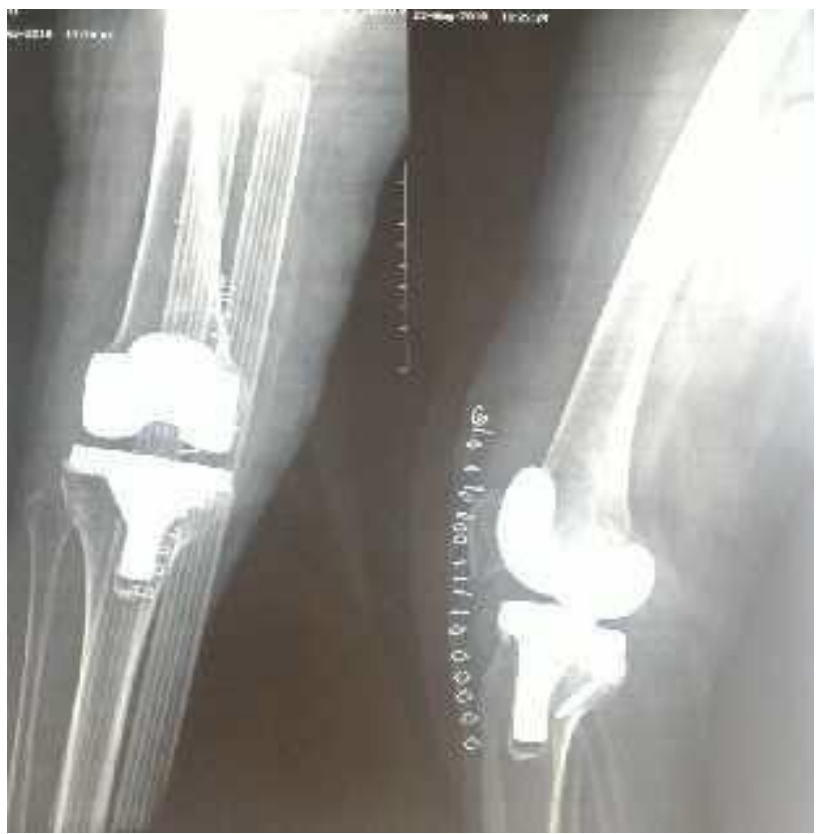

Figure 35.3: Post operative radiograph

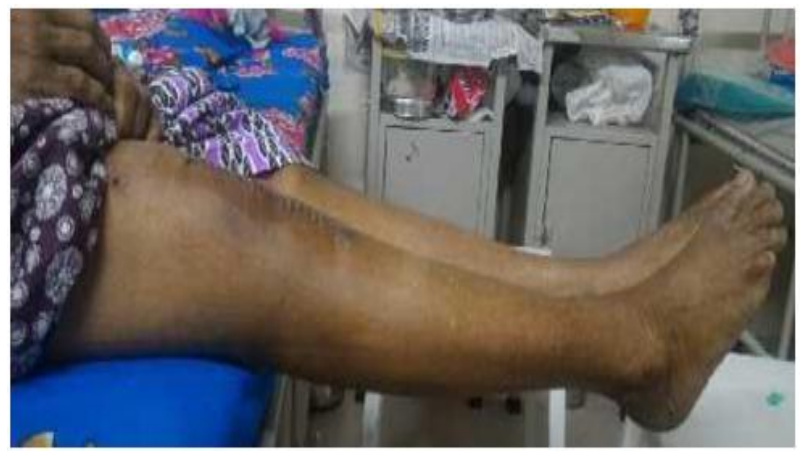

Figure 35.4: Range of motion on $10^{\text {th }}$ post operative day 


\section{JMSCR Vol||08||Issue||05||Page 512-530||May 2020}
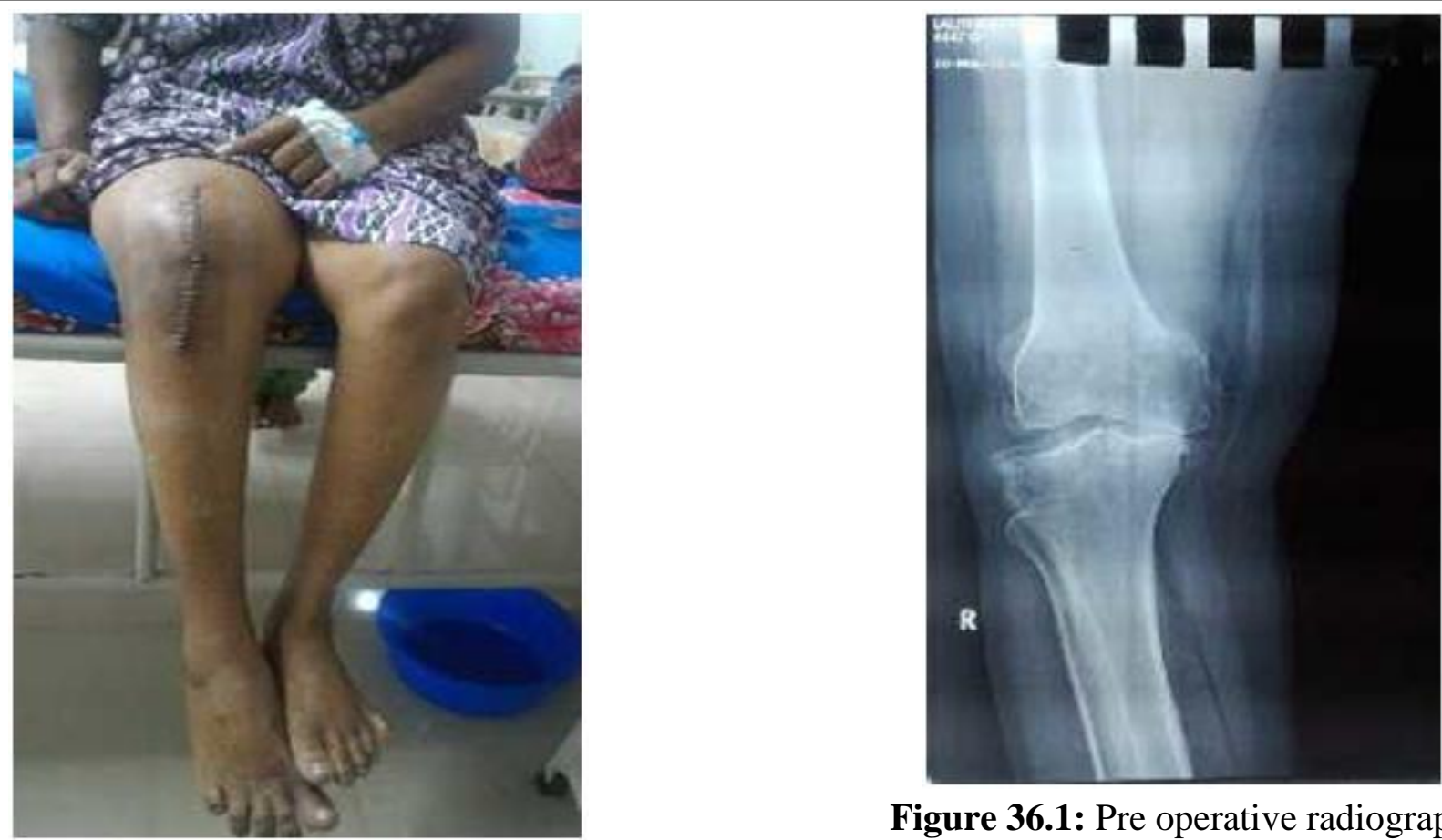

Figure 36.1: Pre operative radiograph

Figure 35.4: Range of motion on $10^{\text {th }}$ post operative day

\section{Case no: 3}

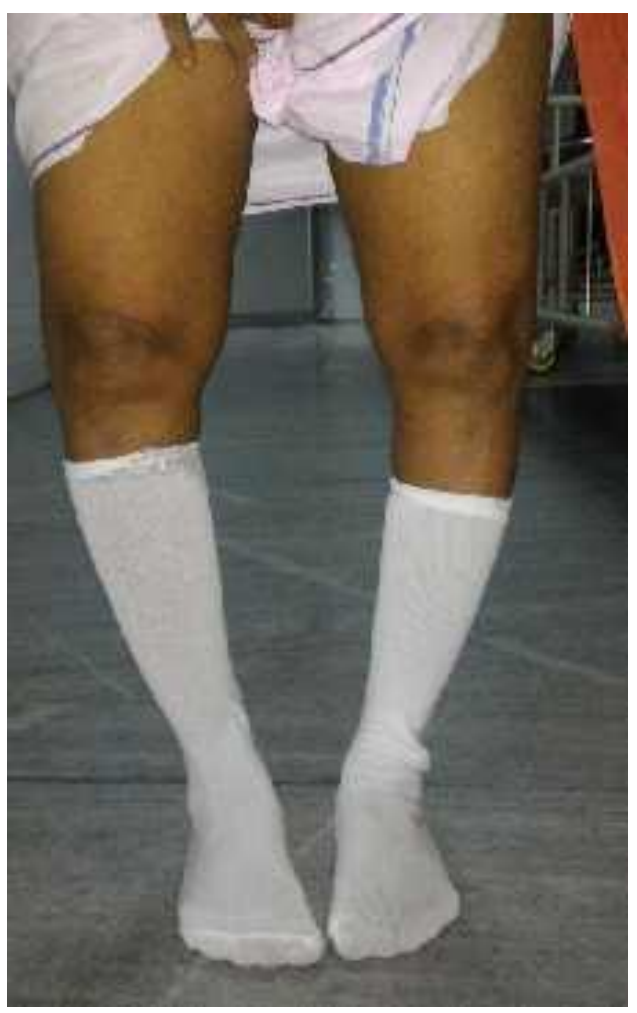

Figure 36.1: Pre operative picture

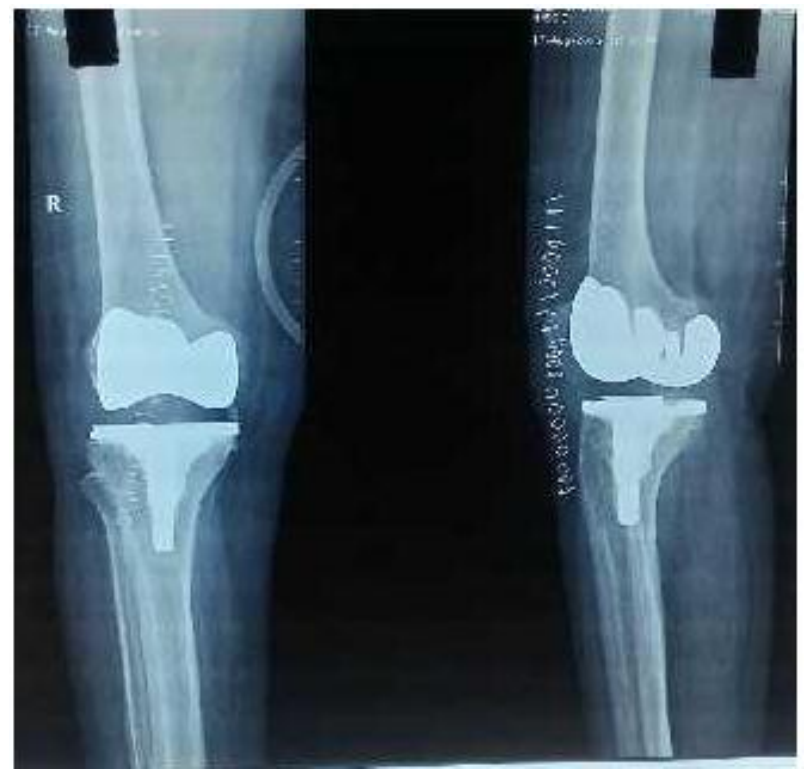

Figure 36.3: Post operative radiograph

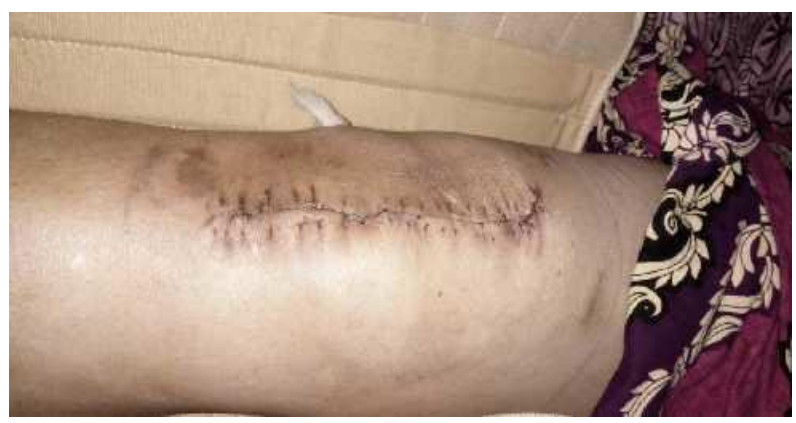

Figure 36.4: Post operative alignment 


\section{Case no: 4}

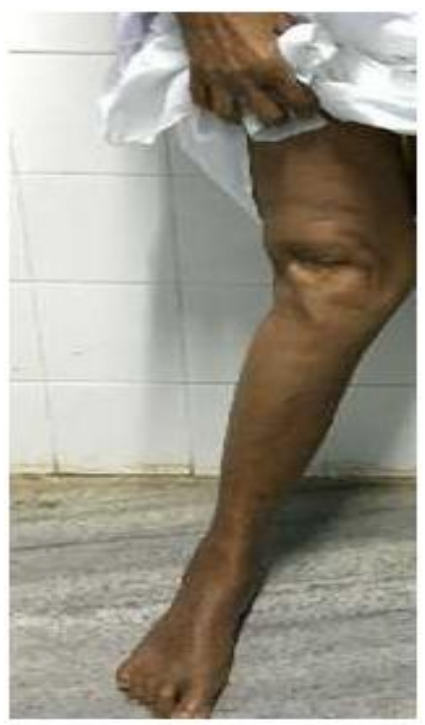

Figure 37.1: Pre operative picture

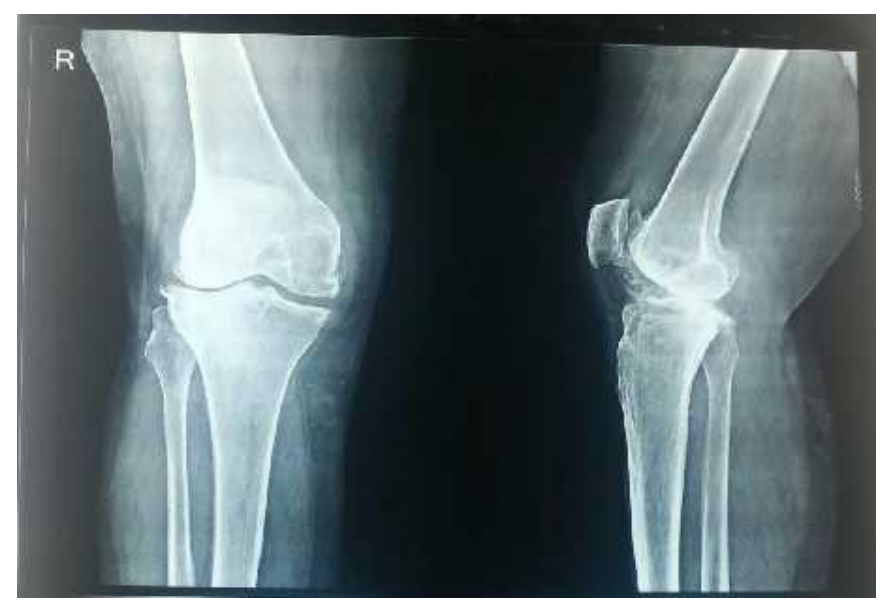

Figure 37.2: Pre operative radiograph

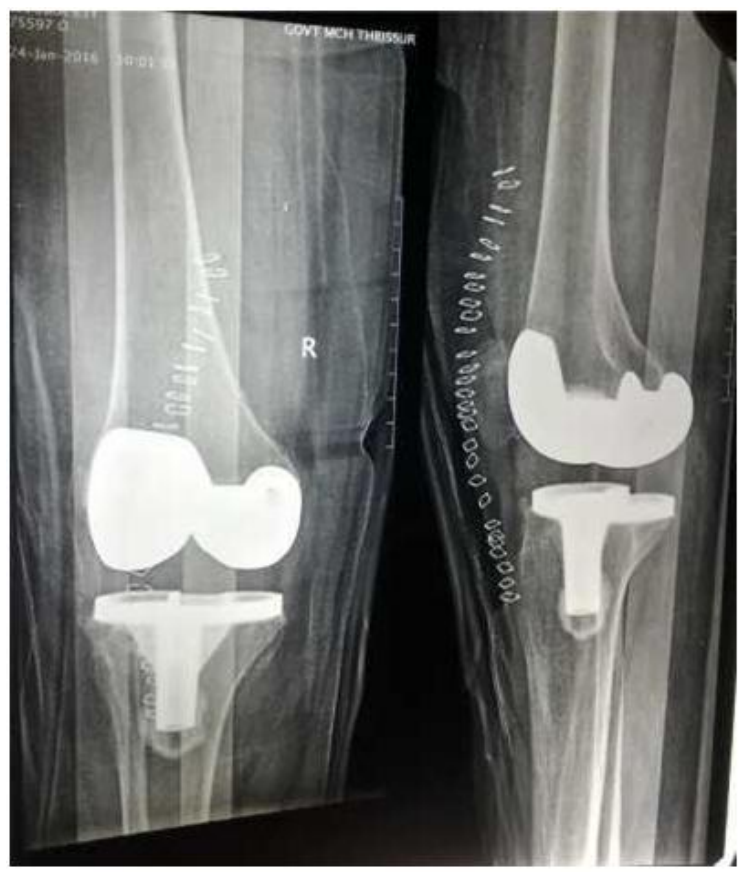

Figure 37.3: Post operative radiograph

\section{Discussion}

Elderly patients who were having difficulty mobilizing because of degenerative arthritis showed good relief after Total Knee Arthroplasty. It was seen there was a substantial relief of pain of joint, increased mobility of the joint, correction of deformity and an improvement in the quality of life of the patients following Total Knee Arthroplasty.

Factors including pain, range of movement (ROM), sociodemographic and clinical data with functional status are discussed. In this study 40 patients who satisfied the inclusion criteria and all the knees were operated using a Posterior cruciate substituting design.

In this study 29 [72\%] subjects were 56 to 77 years old. This is to be expected, as an American profile from 1986-2002, states that arthritic changes in the over 65 years' population, are considered normal $^{105} \cdot 49.7 \%$ of adults more than 65 years reported doctor-diagnosed arthritis from 2010-2012. ${ }^{106 .}$ The age range of study subjects was comparable to literature.

Woman has more chance of getting osteoarthritis knee than men and severe osteoarthritis knee is also more in woman ${ }^{107} .32$ [80\%] subjects in this study were female which is comparable to other studies. In a study on sociodemographic factors affecting total knee arthroplasty outcomes, in the United Kingdom, United States of America and Canada it was found that the majority of participants for TKA's were female [70\%] by davis et al ${ }^{108}$. The incidence of osteoarthritis knee in females is hypothesized as hormonal. But studies show conflicting results ${ }^{109,110 .}$

In vivo studies by Stiehl et al.; Victor, Banks, and Bellemans and Dennis et al., who used fluoroscopy during single-stance deep knee bends to show in some PCL-retaining knees a paradoxical forward translation of the femorotibial contact point while weight bearing and flexion; PCL-substituting knees studied showed more uniform femoral rollback. ${ }^{38,39} \mathrm{C}$. Buz Swanik found that following total knee arthroplasty, patients were able to reproduce the joint position and improve mobility of the joint significantly. 
Retensioned capsulo-ligamentous structure reduces pain and inflammation. Retention of the posterior cruciate ligament does not appear to significantly improve the proprioception and balance compared with those functions in patients with a posterior stabilized total knee design were also seen in the study. ${ }^{111}$

In our study the patella of all patients was circumferentially denervated Total knee arthroplasty with retention of the patella had clinical results that were comparable with those after total knee arthroplasty with patellar resurfacing which was studied by BARRACK et $\mathrm{al}^{112 .}$ He also found out that component design and rotation causes anterior knee pain rather than the patella is resurfaced. Similar study was done by nutton with the same result as that of BARRACK et $\mathrm{al}^{113}$.

Total knee arthroplasty with resurfacing of the patella exhibited significant limitation of extension of knee, which was found to be associated with the presence of anterior knee pain as proposed by Wood ${ }^{114}$

The Knee Society Score rating system was the logical outgrowth of the Hospital for Special Surgery (HSS) rating system. All patients were assessed with Knee Society Scoring system. The Knee Society Score system separates findings in the operated knee with findings in the patient's function. The scoring system combines a relatively objective Knee Clinical Score that is based on the clinical parameters and a Knee Functional Score based on how the patients perceives that knee function with specific activities.

In our study a significant improvement in scores was observed confirming that arthroplasty is a good operating technique allowing persons to get a good functional ability and range of motion with advanced osteoarthritis knee

Knee Society Score 85.5 which is obtained in our study is comparable to that obtained by Giesinger in a one year follow up ${ }^{115}$. The average pre-op Knee Clinical Score was 28.13 which improved to an average post-op score of 95.38 while the average pre-op Knee Functional Score of 41.53, improved to a post-op score of 88.49 in a study done by CHANDRAN R SHETTY ${ }^{116}$

In a study published by A Suhail the average American Knee Society Knee score was found out to be $87.9 \%$ (standard deviation 5.7) with $77.3 \%$ of patients (58 knees) rated excellent, 21.3\% (16 knees) rated good and $1.3 \%$ of patients (1 knee) rated fair. None were rated poor ${ }^{117}$

In our study functional outcome in relation to valgus and varus knee was also studied showing an excellent functional outcome in $90 \%$ of cases with varus knee and excellent functional outcome in $85 \%$ cases with valgus knee in Knee Clinical Score and in Knee Functional Score $74 \%$ of cases showing excellent functional outcome with varus knee and $71 \%$ of cases showing excellent functional outcome in valgus knee.

In a study published by Krackow et al functional outcome of valgus knee was found to be excellent in $87 \%$ of cases ${ }^{118}$. Ranawat et al showed improvements of Knee Clinical Score from a pre operative mean score of 30 points to post operative mean score of 93 points and improvement of Knee Functional Score from a pre operative mean score of 30 to a post operative mean score of 81 in a 5 year follow- up 119 .

In a study published by Kadam et al the mean preoperative Knee Clinical Score of varus knee was 49.40 which increased to a postoperative score of 86.08at the end of 6 months. Similarly, the mean preoperative Knee Functional Score of varus knee was 32.75 which increased to a postoperative score of 84.43 at the end of 6 month showing an excellent outcome ${ }^{120}$

Almost all patients were able to have a good range of motion and a good functional outcome following surgery in our study

\section{Summary}

This study was done in 40 patients aged above 18 years attending Orthopedics department of Medical College Thrissur who underwent Total Knee Arthroplasty from march $1^{\text {st }} 2015$ to September $30^{\text {th }}$ 2016. All these patients were assessed clinically and radiologically preoperatively and evaluated postoperatively with 
Knee Society Scoring system. The findings are summarized below

Majority of the subjects belonged to age group 56-65 [42.5\%] followed by 66- 75 [30\%]

Out of the 40 patients 32[80\%] were female showing a higher incidence of Osteoarthritis in female

Out of the 40 cases operated 22 cases were operated on the left side which accounts for $55 \%$ of the cases

Out of the 40 patients who were operated 34 had excellent Knee Clinical Score after 6 months, 3 had good results and 1 had poor results. 2 patients were excluded due to post operative infection

Out of the 38 patients who were operated pre-op Knee Clinical Score had a mean of 27 with a standard deviation of 6.06. After 3 months post operative score was increased to 85.47 with a standard deviation of 8.16 which further increased to an average of 87.90 with a standard deviation of 7.03 at 6 months showing an excellent outcome

Out of the 40 patients operated 28 had excellent Knee Functional Score after 6 months, 8 had good results and one each had fair and poor results. 2 were excluded from study due to post operative infection

Out of the 40 patients who were done surgery pre-op Knee Functional Score had a mean of 40.37 with a standard deviation of 7.71. After 3 months post operative score was increased to 78.28 with a standard deviation of 7.63 which further increased to an average of 81.05 with a standard deviation of 7.18 showing an excellent outcome

Out of the 38 patients who were operated 31 had varus knee and 7 had valgus knee. On follow up it was seen that 28among the 31 had excellent outcome, 2had a good outcome and 1had poor outcome. Among the 7 with valgus knee 6had an excellent outcome, 1had good outcome and none had poor results.
Out of 38 patients who underwent surgery 31 had varus knee and 7 had valgus knee. On follow up it was seen that 23among the 31 had excellent outcome, 6 had a good outcome, 1 each had a fair had poor outcome. Among the 7 with valgus knee 5had an excellent outcome, 2 had good outcome and none had poor results

Almost all patients were able to have a good range of motion and a good functional outcome following surgery

\section{Bibliography}

1. Symmons D, Mathers C and Pfleger B. 2000. Global burden of osteoarthritis in the year 2000. Documentation for GBD.

2. Bijlsma JW, Berenbaum F, Lafeber FP. Osteoarthritis: an update with relevance for clinical practice. Lancet; 2011 Jun 18;377:2115-26.

3. John N Insall, Lawrence D Dorr, Richard D Scott, W. Norman Scott. Rationale of The Knee Society Clinical Rating System. Clin Orthop 1989 Nov;248:13-14

4. Palmer $\mathrm{H}$ and Cross MJ. 2004. Total knee arthroplasty. < http://www.emedicine.com/orthoped/topic 347.htm

5. Ferguson M. Excision of the knee joint: recovery with a false joint and useful limb. Med Times Gaz 1861;1:601.

6. Campbell WC. Interposition of vitallium plates in arthroplasty of the knee: preliminary report. Am J Surg 1940;47:639.

7. Walldius B. Arthroplasty of the knee joint using endoprosthesis. Acta Orthop Scand 1957;24:19.

8. Shiers LGP. Hinge arthroplasty of the knee. J Bone Joint Surg 1965;47:586.

9. MacIntosh DL. Arthroplasty of the knee. J Bone Joint Surg 1966;48:179.

10. Insall JN, Ranawat CS, Scott WN, Walker PS. Total condylar knee replacement: preliminary report. Clin Orthop1976;120: $149-54$ 
11. Gunston FH. Polycentric knee arthroplasty: prosthetic simulation of normal knee movement. J Bone Joint Surg 1971;53:272

12. Coventry MB, Upshaw JE, Riley LH. Geometric total knee arthroplasty: conception, design, indications, and surgical technique. Clin Orthop Relat Res 1973;94:171-76

13. Marmor L. Marmor modular knee in unicompartmental disease: minimum fouryear follow-up. J Bone Joint Surg 1979;61:347

14. Ranawat CS. Long term results of total condylar knee arthroplasty: a fifteen years survivorship study. Clin Orthop1993;286:94

15. Insall JN, Clarke HD. Historic development classification and characteristics of knee prostheses. New York: Churchill-Livingstone; 2001. p. 1516-53

16. Insall JN, Lachiewicz PF, Burstein AH. The posterior stabilized condylar prosthesis: a modification of total condylar design: two to four year clinical experience. J Bone Joint Surg 1982; 64: 1317

17. Laskin RS, Maruyama Y, Villaneuva M. Deep-dish congruent tibial component use in total knee arthroplasty: a randomized prospective study. Clin OrthopRelat Res 2000;380:36.

18. Easley ME, Insall JN, Scuderi GR. Primary constrained condylar knee arthroplasty for the arthritic valgus knee. Clin OrthopRelat Res 2000;380:58.

19. Rosenberg AG, Verner JJ, Galante JO. Clinical results of total knee revision using the total condylar III prosthesis. Clin OrthopRelat Res 1991;273:83

20. Donaldson III WF, Sculco TP, Insall JN. Total condylar III knee prosthesis: longterm follow-up study. Clin OrthopRelat Res 1988;226:21
21. Marmor L. Unicompartmental arthroplasty of the knee with a minimum tenyear follow-up period. Clin Orthop Relat Res 1988;228:171.

22. Goodfellow JW, O'Connor JJ, Murray DW. Principles of meniscal bearing arthroplasty for unicompartmental knee replacement. Paris: Expansion Scientifique Francaise; 1997

23. Padgett DE, Stern SH, Insall JN. Revision total knee arthroplasty for failed unicompartmental replacement. J Bone Joint Surg 1991;73:186.

24. Scott RD, Cobb AG, McQueary FG. Unicompartmental knee arthroplasty: 8 to 12 years follow-up with survivorship analysis. Clin OrthopRelat Res 1991;271:96.

25. Buechel FF. New jersey low-contact-stress knee replacement system. Clin OrthopRelat Res 1991;264:211.

26. Buechel FF. Mobile-bearing knee arthroplasty: rotation is our salvation. $\mathbf{J}$ Arthroplasty 2004;19:27

27. Jordan LR, Olivo JL, Voorhorst PE. Survivorship analysis of cementless meniscal bearing total knee arthroplasty. Clin Orthop Relat Res 1997;338:119.

28. Callaghan JJ, Squire MW, Goetz DD. Cemented rotating-platform total knee replacement

29. Rand JA, Chao EY, Stauffer RN. Kinematic rotating-hinge total knee arthroplasty. J Bone Joint Surg 1987;69:489

30. Jones RE, Barrack RL, Skedros J. Modular, mobile-bearing hinge total knee arthroplasty. Clin Orthop Relat Res 2001;392:306.

31. Whiteside LA. Soft tissue balancing: the knee. J Arthroplasty 2002;17:23-7.

32. Zalzal P, Papini M, Petruccelli D, de Beer J, Winemaker MJ. An in vivo biomechanical analysis of the soft-tissue envelope of osteoarthritic knees. J Arthroplasty 2004;19:217-23. 
33. Fehring TK, Valadie AL. Knee instability after total knee arthroplasty. Clin OrthopRelat Res 1994;299:157-62.

34. Fehring TK, Odum S, Griffin WL, Mason JB, Nadaud M. Early failures in total knee arthroplasty. Clin Orthop Relat Res 2001;392:315-18.

35. Sharkey PF, Hozack WJ, Rothman RH, Shastri S, Jacoby SM. Why are total knee arthroplasties failing today. Clin OrthopRelat Res 2002;404:7-13.

36. Geert Van Damme. What should the surgeon aim for when performing Computer-assisted Total Knee Arthroplasty. J Bone Joint Surg Am 2005; 87:52-8.

37. Andriacchi TP, Galante JO, Fermier RW. The influence of total knee replacement design on walking and stair climbing. $\mathbf{J}$ Bone Joint Surg 1982;64:1328.

38. Dennis DA, Clayton ML, O'Donnell S. Posterior cruciate condylar total knee arthroplasty: average 11-year follow-up examination. Clin OrthopRelat Res 1992;281:168.

39. Dennis DA, Komistek RD, Stiehl JB. Range of motion after total knee arthroplasty: the effect of implant design and weight-bearing conditions. J Arthroplasty 1998;13:748.

40. Figgie HE, Goldberg VM, Figgie MP. The effect of alignment of the implant on fractures of the patella after condylar total knee arthroplasty. J Bone Joint Surg 1989; $71: 1031$.

41. Hozack WJ, Rothman RH, Booth Jr RE. The patellar clunk syndrome: a complication of posterior stabilized total knee arthroplasty. Clin OrthopRelat Res 1989;241:203

42. Ritter MA, Campbell E, Faris P. Longterm survival analysis of the posterior cruciate condylar total knee arthroplasty: a 10-year evaluation. J Arthroplasty 1989;4:293.
43. Ritter MA, Harty LD, Davis KE. Simultaneous bilateral, staged bilateral, and unilateral total knee arthroplasty: a survival analysis. J Bone Joint Surg 2003;85:1532.

44. Maloney WJ, Schurman DJ. The effects of implant design on range of motion after total knee arthroplasty: total condylar versus posterior stabilized total condylar designs. Clin OrthopRelat Res 1992;278:147.

45. Scott WN, Rubinstein M, Scuderi G. Results after knee replacement with a posterior cruciate-substituting prosthesis. J Bone Joint Surg 1988;70:1163.

46. Laskin RS. Total knee arthroplasty using an uncemented, polyethylene tibial implant: a seven-year follow-up study. Clin OrthopRelat Res 1993;288:270.

47. Laskin RS. The Genesis total knee prosthesis: a 10-year follow up study. Clin OrthopRelat Res 2001;388:95.

48. Faris PM, Herbst SA, Ritter MA. The effect of preoperative knee deformity on the initial results of cruciate-retaining total knee arthroplasty. J Arthroplasty 1992; 7:527.

49. Wasielewski RC. The causes of insert backside wear in total knee arthroplasty. Clin OrthopRelat Res 2002;404:232.

50. Wright TM, Rimnac CM, Stulberg SD. Wear of polyethylene in total joint replacements: observations from retrieved PCA knee implants. Clin OrthopRelat Res 1992;276:126

51. Rose RM, Crugnola A, Ries M. On origins of high in vivo wear rates in polyethylene components of total joint prostheses. Clin Orthop Relat Res 1979;145:277.

52. Dennis DA, Komistek RD, Colwell Jr CE. In vivo anteroposterior femorotibial translation of total knee arthroplasty: a multicenter analysis. Clin OrthopRelat Res 1998;356:47.

53. Puloski SK, McCalden RW, MacDonald SJ. Tibial post wear in posterior stabilized 
total knee arthroplasty: an unrecognized source of polyethylene debris. J Bone Joint Surg 2001;83A:390.

54. O' Rourke MR, Callaghan JJ, Goetz DD. Osteolysis associated with a cemented modular posterior-cruciate-substituting total knee design: five to eight-year follow-up. J Bone Joint Surg 2002;84: 1362.

55. Cook SD. Clinical radiographic and histologic evaluation of retrieved human noncemented porous-coated implants. J Long Tenn Effect Med Implants 1991;1:11.

56. Mayor MB, Collier JP. The histology of porous-coated knee prostheses. Orthop Trans 1986;10:441.

57. Ranawat CS, Johanson NA, Rimnac CM. Retrieval analysis of porous-coated components for total knee arthroplasty. Clin OrthopRelat Res 1986;209:244.

58. Bloebaum RD, Rubman MH, Hofmann AA. Bone ingrowth into porous- coated tibial components implanted with autograft bone chips: analysis of ten consecutively retrieved implants. J Arthroplasty 1992;7:483.

59. Sumner DR, Turner TM, Dawson D. Effect of pegs and screws on bone ingrowth in cementless total knee arthroplasty. Clin OrthopRelat Res 1994;309:150.

60. Duffy GP, Berry DJ, Rand JA. Cement versus cementless fixation in total knee arthroplasty. Clin OrthopRelat Res 1998;356:66.

61. Barrack RL, Nakamura SJ, Hopkins SG. Early failure of cementless mobile bearing total knee arthroplasty. J Arthroplasty 2002;19:101.

62. Engh GA, Ammeen DJ. Periprosthetic osteolysis with total knee arthroplasty. Instr Course Lect2001;50:391.

63. Berger RA, Lyon JH, Jacobs JJ. Problems with cementless total knee arthroplasty at
11 years follow up. Clin OrthopRelat Res 2001;392:196.

64. Buechel FF. Long-term outcomes and expectations: cementless meniscal bearing knee arthroplasty: 7- to 12-year outcome analysis. Orthopedics 1994;17:833.

65. Whiteside LA. Cementless total knee replacement: 9 to 11year results and 10year survivorship analysis. Clin OrthopRelat Res 1994;309:185.

66. Khaw FM, Kirk LM, Gress PT. Survival analysis of cemented press-fit condylar total knee arthroplasty. J Arthroplasty 2001;16:161

67. Bellamy N, Buchannan WW, Goldsmith CH, Campbell J and Stitt LW. 1988. Validation study WOMAC: a health status instrument for measuring clinicallyimportant patient-relevant outcomes following total hip or knee arthroplasty in osteoarthritis. Journal of Orthopaedic Rheumatology, vol. 15, pp. 95-108.

68. Mamlin LA, Melfi CA, Parchman ML, Gutierrez B, Allen DI et al. 1998. Management of osteoarthritis of the knee by primary care physicians. Archives of Family Medicine, vol. 7, pp. 563-567.

69. Milne AD, Evans NA and Stanish WD. 2000. Nonoperative management of knee osteoarthritis - diagnosis, behaviour modification, and pharmalogical options. Women's Health in Primary Care, vol. 3, no. 12 , pp. 841-846.

70. Kelley LTMT. 2006. Nonsurgical management of osteoarthritis of the knee. JAAPA, vol. 19, no. 1, pp. 26-32

71. Rosneck J, Higuera CA, Tadross N, Krebs $\mathrm{V}$ and Bersoum WK. 2007. Managing knee osteoarthritis before and after arthroplasty. Cleveland Clinic Journal of Medicine, vol. 74, no. 9, pp. 663-671

72. Tidswell M. 1998. Orthopaedic Physiotherapy. London: Mosby International Limited

73. Laskin RS. Total knee replacement in patients older than 85 years. 1999. Clinical 
Orthopaedics and Related Research, vol. 367, pp. 43-49

74. March LM and Bagga H. 2004. Epidemiology of osteoarthritis in Australia. MJA, vol. 180, pp. 6-10

75. Crowder AR, Duffy GP, Trousdale RT. Long-term results of total knee arthroplasty in young patients with rheumatoid arthritis. J Arthroplasty 2005 Oct;20:12-6

76. Hanssen AD, Rand JA. Evaluation and treatment of infection at the site of a total hip or knEe arthroplasty. Instr Course Lect1999;48:111.

77. Salvati EA, Robinson RP, Zeno SM. Infection rates after 3175 total hip and total knee replacements performed with and without a horizontal unidirectional filtered air-flow system. J Bone Joint Surg 1982;64:525.

78. Wilson MG, Kelley K, Thornhill TS. Infection as a complication of total kneereplacement arthroplasty. J Bone Joint Surg 1990;72:878.

79. Kim J, Nelson CL and Lotke PA. 2004. Stiffness after total knee arthroplasty. The Journal of Bone and Joint Surgery, vol. 86A, no. 7, pp. 1479-1484.

80. Lidwell OM. Clean air at operation and subsequent sepsis in the joint. Clin OrthopRelat Res 1986;211:91.

81. Salvati EA, Robinson RP, Zeno SM. Infection rates after 3175 total hip and total knee replacements performed with and without a horizontal unidirectional filtered air-flow system. J Bone Joint Surg 1982;64:525

82. Kaufer H, Matthews LS. Resection arthroplasty: an alternative to arthrodesis for salvage of the infected total knee arthroplasty. Instr Course Lect 1986;25:283

83. Falahee MH, Matthews LS, Kaufer H. Resection arthroplasty as a salvage procedure for a knee with infection after a total arthroplasty. J Bone Joint Surg 1987;69:1013.

84. Damron TA, McBeath AA. Arthrodesis following failed total knee arthroplasty: comprehensive review and meta-analysis of recent literature. Orthopedics 1995;18:361.

85. Göksan SB, Freeman MAR. One-stage reimplantation fo $r$ infected total knee arthroplasty. J Bone Joint Surg 1992;74:78.

86. Silva M, Tharani R, Schmalzried TP. Results of direct exchange or debridement of the infected total knee arthroplasty. Clin OrthopRelat Res 2002;404:125.

87. Insall JN, Thompson FM, Brause BD. Two-stage reimplantation for the salvage of infected total knee arthroplasty. J Bone Joint Surg 1983;65:1087.

88. Windsor RE, Insall JN, Urs WK. Twostage reimplantation for the salvage of total knee arthroplasty complicated by infection. J Bone Joint Surg 1990;72:272.

89. Rosenberg AG, Haas B, Barden R. Salvage of infected total knee arthroplasty. Clin OrthopRelat Res 1988;226:31

90. Woolson ST, Pottorff G. Venous ultrasonography in the detection of proximal vein thrombosis after total knee arthroplasty. Clin Orthop Relat Res 1991;273:131.

91. Haas SB, Tribus CB, Insall JN. The significance of calf thrombi after total knee arthroplasty. J Bone Joint Surg 1992;74:799.

92. Lotke PA, Palevsky H, Keenan AM. Aspirin and warfarin for thromboembolic disease after total joint arthroplasty. Clin OrthopRelat Res 1996;324:251.

93. Westrich GH, Haas SB, Mosca P. Metaanalysis of thromboembolic prophylaxis after total knee arthroplasty. J Bone Joint Surg 2000;82:795.

94. Westrich GH, Sculco TP. Prophylaxis against deep venous thrombosis after total knee arthroplasty: pneumatic plantar 
compression and aspirin compared with aspirin alone. J Bone Joint Surg 1996;78:826.

95. Brick GW, Scott RD. The patellofemoral component of total knee arthroplasty. Clin OrthopRelat Res 1988;231:163.

96. Ortiguera CJ, Berry DJ. Patellar fracture after total knee arthroplasty. J Bone Joint Surg 2002;84:532.

97. Idusuyi OB, Morrey BF. Peroneal nerve palsy after total knee arthroplasty. J Bone Joint Surg 1996;78:177

98. Lesh ML, Schneider DJ, Deol G. The consequences of anterior femoral notching in total knee arthroplasty. J Bone Joint Surg 2000;82:1096

99. Ritter MA, Thong AE, Keating EM. The effect of femoral notching during total knee arthroplasty on the prevalence of postoperative femoral fractures and on clinical outcome. J Bone Joint Surg 2005;87:2411

100. C. Buz S wanik. Proprioception, kinesthesia, and balance after total knee arthroplasty with cruciate retaining and posterior stabilized prostheses, $\mathrm{J}$ Bone Joint Surg 2004;86:328-34.

101. Healy WL, Siliski JM, Incavo SJ. Operative treatment of distal femoral fractures proximal to total knee replacements. J Bone Joint Surg 1993;75:27.

102. Ritter MA, Keating EM, Faris PM. Rush rod fixation of supracondylar fractures above total knee arthroplasties. J Arthroplasty 1995;10:213.

103. Turek's Orthopaedics: Principles and Their Application, 6th Edition part 2 page 152-156

104. Frederick CE. The knee society total knee arthroplasty roentgenographic evaluation and scoring system. Clin Orthop 1989 Nov;248:9-12

105. Crowninshield RD, Rosenberg AG and Sporer SM. 2006. Changing demographics of patients with total joint replacement. Clinical Orthopaedics and Related Research, vol. 443, pp. 266-272

106. Srikanth VK, Fryer JL, Zhai G, Winzenberg TM, Hosmer D, Jones G. A metaanalysis of sex differences prevalence, incidence and severity of osteoarthritis.2005 Sep; 13(9):769-81

107. Barbour KE, Helmick CG, Theis KA, Murphy LB, Hootman JM, Brady TJ, et al. Prevalence of Doctor-Diagnosed Arthritis and Arthritis-Attributable Activity Limitation- United States, 2010-2012. Morb Mortal Wkly Rep. 2013;62(44):869-873

108. Davis ET, Lingard EA, Schemitschi EH and Waddell JP. 2008. Effects of socioeconomic status on patients' outcome after total knee arthroplasty. International Journal for Quality in Health Care, vol. 20, pp. 40-46.

109. Wluka AE, Cicuttini FM, Spector TD Maturitas Menopause, oestrogens and arthritis. 2000 Jun 30; 35(3):183-99.

110. Nevitt MC, Cummings SR, Lane NE, Hochberg MC, Scott JC et al. Association of estrogen replacement therapy with the risk of osteoarthritis of the hip in elderly white women. Study of Osteoporotic Fractures Research Group.Arch Intern Med. 1996 Oct 14; 156(18):2073-80.

111. C. Buz Swanik. Proprioception, kinesthesia, and balance after total knee arthroplasty with cruciate retaining and posterior stabilized prostheses, J Bone Joint Surg 2004;86:328-34

112. Robert L Barrack. Resurfacing of the patella in total knee arthroplasty: a prospective, randomized, double-blind study. J Bone Joint Surg 1997;79:112131.

113. Nutton. The functional outcome following total knee replacement with or without patella resurfacing. British Association For Surgery of the Knee 2001:27-28. 
114. Wood. Clinical outcomes and walking analysis after total knee arthroplasty with and without patellar resurfacing: a prospective randomized trial. J Bone Joint Surg 2005:338-39

115. Johannes M. Giesinger, David F. Hamilton, Bernhard Jost ${ }^{\mathrm{c}}$, Henrik Behrend , Karlmeinrad Giesinger. A study of functional outcome of TKA in the American journal of arthroplasty 2015

116. Chandran R, Shetty SK, Shetty A, Balan B, Lawrence J Mathias LJ. A study of functional outcome after Primary Total Knee Arthroplasty in elderly patients. IAIM, 2016; 3(7): 297-301

117. A Suhail, H Idha, MY Norhamdan, Y Shahril, O Masbah. A study of functional outcome of OA Knee after TKA using Knee society score .MALASIAN JOURNAL OF ORTHOPAEDICS 2009 Vol3No2

118. Krackow KA. The technique of total knee arthroplasty. St. Louis: Mosby; 1990.

119. Ranawat AS, Ranawat CS, Elkus M, Rasquinha VJ, Rossi R, Babhulkar S. Total knee arthroplasty for severe valgus deformity. J Bone Joint Surg Am. 2005;87(Suppl 1(Pt 2)):271-284

120. Rahul V. Kadam, Sunil Yadav, Abhay Chhallani, Chinmoy Sharma. Indian Journal of Orthopedics. Int J Res Orthop 20163537. 